UDC 378.147.31

DOI https://doi.org/10.32840/1992-5786.2020.72-2.30

D. S. Chernyak

Candidate of Sociological Sciences, Associate Professor, Associate Professor at the Department of Philosophy, Political Science and Ukrainian Studies Kyiv National University of Technology and Design

T. I. Kadlubovich

Candidate of Sociological Sciences, Associate Professor Associate Professor at the Department of Philosophy, Political Science and Ukrainian Studies Kyiv National University of Technology and Design

I. V. Zagrebelna

Student

Kyiv National University of Technology and Design

\title{
PROSPECTS OF USING SOCIAL NETWORKS IN THE EDUCATIONAL PROCESS
}

The article is devoted to the problems of using social networks in the educational space. A number of scientific literature on the outlined issues are analyzed, conclusions are made. It is noted that the information society is characterized by a rapid growth of information, the transformation of knowledge into social capital. The advantages and disadvantages of using social networks in the educational space are pointed out, the methods of work are analyzed. It was found that student youth is attracted by the opportunity to study through social networks: it is fashionable, convenient, modern. Such training provides an opportunity of constant contact with the teacher, an opportunity to use various Internet resources, to study remotely. Among the disadvantages of using social networks in the educational area, the main, according to the authors, is the lack of direct contact "teacher-student", which prevents the transfer of natural emotions, live visual contact, and makes not quite objective control and assessment of students. But the analysis of the modern educational process has shown that the advantages of using social networks are much greater. Provided that the teacher prepares quality educational content, offers verified information, and students have the skill to critically evaluate information coming from the Internet, then all forms of educational activities - lectures, seminars, round tables, debates, conferences, etc. - become more interesting, creative, modern. Methods of working in social networks are webinars, video conferences, interactive quests, Google expeditions, etc. To do this, there are widely available applications that can be used by the average Internet user. In addition, there is space for the creativity of the students themselves: infographics, posters, presentations (personal and collective). Audio (audio books, speeches by political leaders, interviews, etc.) and video (photo, documentaries, elements of educational TV programs, pages of rare documents, etc.) can be used for educational purposes. There are huge opportunities for a variety of homework and independent tasks: creating a "timeline" (in the study of the history of philosophy, political science, sociology), conducting sociological research, "visiting" a museum, city and even era, etc.

The main thing is that working with social networks encourages students to learn, master the profession.

Key words: information and communication technologies, social network, teaching methods.

Formulation of the problem. A new type of civilization is widely involved in information technology, as it has knowledge-intensive production, and knowledge has become the main social capital. There is a problem of modernization of the education system, which should use the latest teaching methods and tools, in particular, social networks and other Internet resources.

Modern information society with the rapid growth of information, active use of Internet resources, information and communication technologies, changing traditional forms of communication puts forward new requirements for the education system, including the introduction of distance learning, the use of social networks in the educational process, that gained the relevance in time of pandemic.
Analysis of the problem of using social networks in the educational process is the subject of research by many scientists and educators. Attention is paid to the role, functions, opportunities, advantages and disadvantages, experience of using social networks in the educational process. But the methods and prospects of using social networks in the learning process are insufficiently researched.

Analysis of recent research and publications. Modern research on virtual communication, in particular, social networks, is quite diverse. Thus, O. Laba [9] analyzes the functions of social networks. O. Slobodyanyk [12], N. Shulska, N. Matviychuk [15] consider the role of social networks in the educational process. F. Mainaev [10] points to the possibilities of social networks for advertising of higher 
education institutions. R. Hnatyuk [5], K. Varyvoda [4] and others emphasize the advantages and disadvantages of using social networks. Social networks in the works of $Z$. Bauman [2] are severely criticized, and G. Kuchakovska [8], L. Panchenko and others focus on the advantages of social networks in education.

The purpose of the article is to outline the prospects for the use of social networks in the educational space.

Presenting main material. Modern culture and its trends require from education not only the effectiveness of knowledge transfer processes, focus on professionalism and utilitarianism, but also innovations based on a synergetic approach, "interdisciplinarity and dialogue in learning, developing new values of tolerance, competence, criticism, etc." [11, c. 30]. This is facilitated by the use of various Internet resources in the educational process, in particular, social networks.

Information technology has turned knowledge into intellectual capital, made it a center of culture free from traditional constraints. "The main value is the value embodied in knowledge and created by it" [11, c. 33-34].

Social networks are defined as "an online platform that is used to communicate, create social relationships with other people with similar interests, for entertainment, work" [13]. It is a "virtual platform that provides its means of communication, support, creation, development, display and organization of social contacts, including data exchange between users, which involves the prior creation of an account" $[7 ; 15]$.

Today, there are about 3.5 billion users of social networks in the world, the most popular of which are Facebook, You Tube, WhatsApp, Instagram, Twitter, Pinterest, Linkedln, TikTok and others. 19 million Ukrainians are Facebook users. This social network is the leader in the list of popular social networks in Ukraine (and in the world), the second place is occupied by Instagram [14].

With the help of Internet resources there is communication, exchange of information and knowledge, societies are created according to interests and preferences, job search, doing business, they are used as an opportunity to spend leisure time, have fun. It is clear that young people are active users of Internet resources, especially social networks. Communicating on social networks, young people share useful links to educational materials, discuss current issues, "throw" each other homework (experience shows that during the lesson it is written down only by some students or the group leader) and try to solve them with together efforts. Teachers can easily "find" a student, because, as a rule, today few people let go of their gadgets and do not "hang" on social networks.
Among the problems that may arise when using social networks in the educational process are: insufficient level of qualification in the field of information and communication technologies and additional burden on the teacher, inability to take into account the "work" of the teacher in the network for remuneration, lack or low level of etiquette online communication), censorship, a significant share of entertainment content, a high degree of labor costs for the organization and support of the educational process online.

Therefore, many who criticize social networks and deny their use in the educational process. For example, the well-known English sociologist Z. Bauman notes that social networks are a trap because they "do not teach dialogue, because it is very easy to avoid controversy. Many people use social networks not to unite, not to expand their horizons, but on the contrary - to lock themselves in what I call a comfort zone." [2]. Social networks are often called time-eaters, a platform for entertainment and informal communication. Disadvantages associated with the use of social networks include Internet addiction, the spread of spam, loss of personal data, the problem of information confidentiality, creating a negative image, redundancy of information and communication, the possibility of stress and fatigue, lack of attention, superficial perception of information.

But the benefits of using social networks are much greater.

The advantages of social networks include a variety of forms of communication (sending personal messages, forums, voting, polls, comments, etc.), the ability to overcome communication barriers that arise in direct communication, "accessibility" of teachers, extensive demonstration opportunities of social networks. It is possible to overcome the lack or insufficiency of technical equipment of the classroom of educational institutions, access to text, audio, video materials, images that can be used for self-education, remote counseling, prompt notification of changes in the educational process, cooperation after completing a course. The use of social networks in the educational process helps to learn to search, analyze and filter information, track content, acquire skills in using information technology, to form a culture of communication in a virtual environment, teamwork skills, when students act as co-authors in creating online learning. content, to involve young people in project activities. The use of social networks meets the needs of modern youth - Z-generation, who do not imagine themselves without electronic communication and for whom the ideology and interface of social networks are clear, which, according to researchers, is another advantage because it saves time to adapt to new communication environment.

Social networks as an environment of teaching and student communication are attractive because you can get additional advice at a convenient time, 
have access from any device (smartphone, tablet, laptop), learning becomes informal, psychologically comfortable, creative, interactive. The advantages of using social networks include: acquiring information navigation skills, the use of network services in professional activities. The use of social networks, according to researchers, does not require money, allows students to be absent from class, watch and participate in educational work online, promotes independence, allows the teacher to better remember students and understand their interests [8].

Through social networks, the activities of higher education institutions are popularized, the advantages and attractiveness of education, scientific and educational achievements of a particular educational institution are noted, which is caused by the desire to win the competition for applicants. Students have the opportunity to choose courses for listening, which, in turn, encourages teachers to be interesting and compete with colleagues, and therefore use social networks for educational purposes. Social networks make it possible to organize joint work with students in an interactive mode, to create societies (for example: associations of members of a scientific circle). Teachers' blogs are also gaining popularity. Scientists note that the use of social networks in the educational process stimulates cognitive and creative activity of students, motivates to work. For example (from the experience of the Department of Philosophy, Political Science and Ukrainian Studies), on the department's Facebook page teachers announce and cover information about educational, scientific, creative activities, which allows students to learn about the department, find like-minded people, discover their talents, understand that learning is not limited to working in the classroom during the lesson, but to see different formats and platforms for self-education and self-realization. Teachers "work" in social networks allows cooperation, exchange of experience with colleagues from around the world, receive information about innovations in the educational process, the latest teaching methods.

The important role of social networks in creating a positive image of the institution in the eyes of the public, especially young people, as a source of additional advertising. For example, $\mathrm{O}$. Laba, analyzing the functions of social networks (informative, communicative, educational, information-analytical, educative, entertaining, organizational functions), also identifies image, advertising and information, career guidance [9]. F. Mainaev, considering social networks as a tool for advertising higher education institutions, a platform for on-line courses, a way to create educational online content, provides the following information: "According to research from the University of Massachusetts, $98 \%$ of higher education institutions in the USA have their official Facebook pages, on Twitter $-86 \%$, on Linkedln - 47\%» [10]. Keeping in touch with former graduates who have started self-employment through social networks can also be useful and serve as a basis for cooperation (science, education and business) and orientation of students for employment, to become an incentive for successful learning.

In general, based on experience, it can be argued that the use of social networks in the educational process allows to implement in the education system a synergetic approach, the principles of open education and academic freedom. In the space of social networks there are opportunities for cooperation, access to information with the possibility of in-depth acquaintance with a huge number of approaches to the problem and options for its solution. The informal psychological climate of "augmented reality" allows a more creative approach to solving problems. Traditional teaching methods (lectures and seminars) are taking on a new form. Through Internet links it is possible to watch documentaries, educational programs, etc. The Internet is also a visualization of the material, its deepening. Methods of working with students are interactive quests, trips to museums and "time ribbons", Google expeditions, creating infographics, posters, presentations, video courses. An interesting method of work is to create a group presentation, when the author of one slide of the presentation is an individual student. There is an opportunity to hold webinars, online conferences, round tables, where not only information is provided, but also there is an opportunity to discuss, express your own opinions.

However, an important problem when working with social networks is teaching students to use information from the World Wide Web, fostering a culture of working with information, the formation of respect for copyright, the development of critical thinking in the perception of the material. On the other hand, the teacher must be aware of the latest programs and applications that will be useful in the preparation of educational content.

Conclusions and suggestions. Despite the fact that today social networks are considered as an important educational tool, a means of involvement in the educational and communicative environment, didactic continuum, an effective interactive platform, their role should not be exaggerated, but also neglected, discounted.

\section{References:}

1. Аснович Н.Г. Использование социальных сетей в образовательном процессе. Информационные технологии в образовании, науке и производcmве : IV Международная научно-техническая интернет-конференция, 18-19 ноября 2016 г. URL : http://rep.bntu.by/handle/data/27254.

2. Бауман 3. Соціальні мережі - це пастка. URL : www.zbruc.eu. 
3. Бєлінська О.Н. Сучасні дослідження віртуальної комунікації: проблеми, гіпотези, результати. URL : www.psychology.ru/internet.

4. Варивода К.С. Позитивні й негативні аспекти взаємодії сучасної молоді в соціальних мережах. Науковий огляд. 2015. № 7 (17). C. $197-213$.

5. Гнатюк Р. Соціальні мережі: співвідношення позитиву і негативу? URL : http://gazeta.dt.ua/ family/socialni-merezhispivvidnoshennyapozitivui-negativu.html.

6. Данько Ю.А. Соціальні мережі як форма сучасної комунікації: плюси і мінуси. Сучасне суспільство: політичні науки, соціологічні науки, культурологічні науки. 2012. С. 179-184.

7. Івашньова С.В. Використання соціальних сервісів та соціальних мереж в освіті. Наукові записки НДУ ім. М. Гоголя. Психологопедагогічні науки. 2012. № 2. С. 15-17.

8. Кучаковська Г.А. Роль соціальних мереж в активізації процесу навчання інформаційних дисциплін майбутніх вчителів початкової школи. Інформаційні технології $і$ засоби навчання. 2015. Т. 47. № 3. С. 136-149.
9. Лаба О.В. Використання соціальних мереж у навчальному процесі. Молодий вчений. 2017. № 3(43). C. 227-231.

10.Майнаєв Ф.Я. Використання соціальних мереж у on-line-навчанні. Innovative solutions in modern science. 2016. № 2(2).

11. Огурцов А.П., Платонов В.В. Образы образования. Западная ффилософия образования. XX век. Санкт-Петербург : РХГИ, 2004. 520 с.

12.Слободяник О.В. Українські соціальні мережі в навчально-виховному процесі. URL : www.lib. iitta.gov.ua.

13.Социальна сеть. URL : https://ru.wikipedia.org/.

14.Социальные сети, самые популярные в Украине и странах мира. URL : www.marketer.ua.

15.Шульська Н.М., Матвійчук Н.М. Соціальні мережі як ефрективне середовище викладацько-студентської комунікації в навчальному процесі. Інфоормаційні технології $і$ засоби навчання. 2017. Т. 58. № 2. С. 155-168.

16. Щербаков О.В, Щербина Г.А. Соціальна мережа для підтримки навчального процесу у ВНЗ. Системи обробки інформації. 2012. Вип. 8 (106). С. 159-162.

\section{Черняк Д. С., Кадлубович Т. І., Загребельна І. В. Перспективи використання соціальних мереж в освітньому процесі}

Статтю присвячено проблемам використання соціальних мереж в освітньому просторі. Проаналізовано низку наукової літератури з окресленої проблематики, зроблено висновки. Зазначено, що інформаційне суспільство характеризується швидкоплинним зростанням обсягів інформації, перетворенням знання на соціальний капітал. Указано на переваги та недоліки використання соціальних мереж в освітньому просторі, проаналізовано методи роботи. Виявлено, що студентську молодь приваблює можливість навчання через соиіальні мережі: ие модно, зручно, сучасно. Таке навчання надає можливість постійного контакту з викладачем, змогу використовувати різноманітні Інтернет-ресурси, навчатися дистанційно. Серед недоліків використання соціальних мереж в освітньому просторі головним, на думку авторів, є відсутність безпосереднього контакту «викладач - студент», що унеможливлює передачу природних емоцій, живий візуальний контакт, а також робить не зовсім об'єктивним контроль та оцінку знань студентів. Але аналіз сучасного навчального процесу довів, що переваг у використанні соціальних мереж значно більше. За умови якщо викладач якісно готує освітній контент, пропонує перевірену інформацію, а у студентів сфрормовано навичку критично оцінювати інформацію, яка надходить з Інтернету, то всі фрорми навчальної діяльності - лекції, семінарські заняття, круглі столи, диспути, конфреренції тощо стають більш цікавими, творчими, сучасними. Методами роботи в соціальних мережах є вебінари, відеоконференції, інтерактивні квести, гугл-експедиції тощо. Для цього в широкому доступі існують додатки, якими може скористатися середньостатистичний користувач Інтернету. Окрім того, є простір для творчості самих студентів: інфрографрія, постери, презентації (особисті та колективні). Із навчальною метою можуть використовуватися аудіо- (аудіокниги, виступи політичних лідерів, інтерв'ю тощо) та відео- (фото, документальні фрільми, елементи навчальних телепрограм, сторінки рідких документів тощо) матеріали. Величезні можливості є й для урізноманітнення домашніх та самостійних завдань. Ними можуть бути створення "стрічки часу» (під час вивчення історії фрілософії, політології, соціології), проведення соціологічного дослідження, відвідування певного музею тощо.

Головне, що робота із соціальними мережами спонукає студента вчитися, пізнавати, оволодівати профресією.

Ключові слова: інформаційно-комунікативні технології, соціальна мережа, методи навчання. 